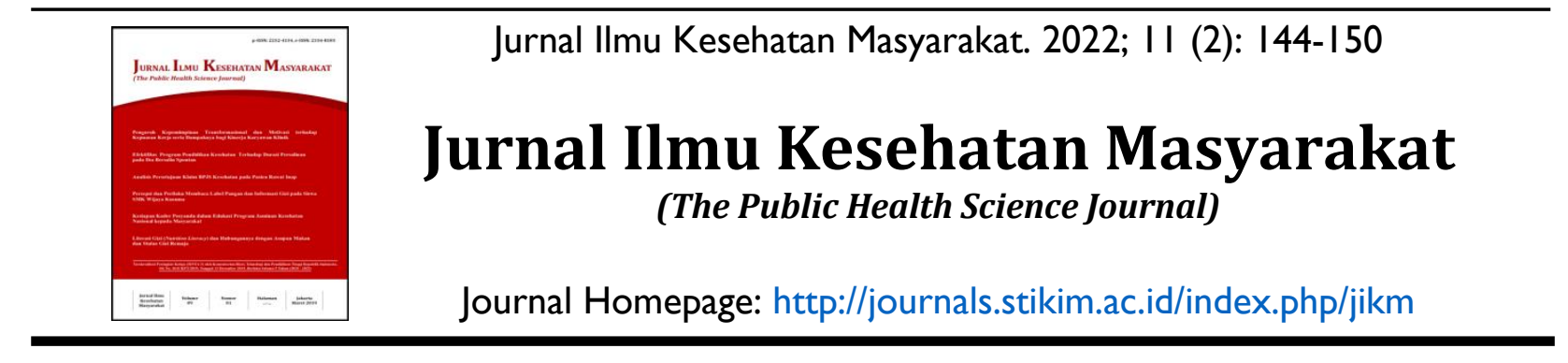

\title{
Hubungan Mutu Pelayanan Kesehatan terhadap Kepuasan Pasien BPJS Kesehatan
}

\author{
Feva Tridiyawati ${ }^{1 *}$, Deska Prahasta ${ }^{2}$ \\ ${ }^{1}$ Program Studi Kebidanan, Sekolah Tinggi Ilmu Kesehatan Abdi Nusantara Jakarta \\ ${ }^{2}$ Program Studi Keperawatan, Sekolah Tinggi Ilmu Kesehatan Abdi Nusantara Jakarta
}

\begin{abstract}
Abstrak
Salah satu upaya pemerintah dalam memberikan pelayanan kesehatan di masyarakat adalah dengan memberikan jaminan kesehatan berupa BPJS, namun pelayanan kesehatan yang kurang baik akan menimbulkan rasa kecewa bagi para peserta BPJS Kesehatan. Tujuan dari penelitian ini adalah untuk mengetahui hubungan mutu pelayanan Kesehatan terhadap kepuasan pasien BPJS Kesehatan di RS Bhakti Husada tahun 2020. Penelitian ini merupakan penelitian analisis kuantitatif observasional menggunakan desain analitik cross sectional, menggunakan sampel sebanyak 100 orang. Sampel diambil menggunakan metode accidental sampling. Pengumpulan data menggunakan kuesioner. Analisa data dilakukan dengan menggunakan uji Chi-Square. Hasil penelitian ini menunjukkan bahwa ada hubungan antara mutu pelayanan Kesehatan terhadap dimensi kehandalan (reliability) $(\mathrm{Pv}=0,000)$, ketanggapan (responsiveness) $(\mathrm{Pv}=0,000 ; \mathrm{OR}=8 \mathrm{I}, 889)$, jaminan (assurance) $(\mathrm{Pv}=0,00 \mathrm{I} ; \mathrm{OR}=25,000)$, empati (empathy) $(\mathrm{Pv}=0,000 ; \mathrm{OR}=74,000)$ dan bukti fisik (tangiable) $(\mathrm{Pv}=0,000 ; \mathrm{OR}=18,000)$. Kesimpulnya penelitian ini bahwa ada hubungan antara mutu pelayanan pasien BPJS Kesehatan dengan kepuasan pasien.
\end{abstract}

Kata Kunci: BPJS Kesehatan, Kepuasan Pasien, Mutu Pelayanan Kesehatan, Rumah Sakit.

\begin{abstract}
One of the government's efforts in providing health services in the community is to provide health insurance in the form of BPJS, but poor health services will cause disappointment for BPJS Health participants. The purpose of this study was to analyze the level of satisfaction of BPJS Kesehatan patients with the quality of health services at Bhakti Husada Hospital in 2020. This study was an observational quantitative analysis study using a cross-sectional analytic design, using a sample of 100 people. Samples were taken using the accidental sampling method. Collecting data using a questionnaire. Data analysis was carried out using the Chi Square test. The results of this study show that there is a relationship between service quality dimensions of reliability $(P v=0.000)$, responsiveness $(P v=0.000 ; O R=8 I .889)$, assurance $(P v=0.001 ; O R=25.000)$, empathy $(P v=0.000 ; O R=74.000)$ dan tangiable $(P v=0.000 ; O R=18.000)$. The conclusion is that there is a relationship between the service quality of BPJS Health patients and patient satisfaction.
\end{abstract}

Keywords: Healthcare and Social Security Agency, Patient Satisfaction, Quality of Health Services, Hospitals.

Korespondensi*: Feva Tridiyawati, Program Studi Kebidanan, Sekolah Tinggi Ilmu Kesehatan Abdi Nusantara Jakarta, Jl. Swadaya Kubah Putih No.7 RT 00I/0/4 Kelurahan Jatibening Kecamatan Pondok Gede Bekasi. E-mail: feva_tridiyawati@yahoo.com, No.Telp: +628/213/40867 


\section{Pendahuluan}

Universal Health Coverage (UHC) yaitu semua orang menerima layanan kesehatan esensial yang mereka butuhkan, tanpa menderita kesulitan keuangan adalah target nomor 3.8 dari Sustainable Development Goals (SDG). Namun, di banyak negara berpenghasilan menengah ke bawah (lower-middle-income countries, LMCs), kesenjangan cakupan yang besar tetap ada. Lebih lanjut, mereka yang mengakses layanan sering kali mengalami pengeluaran biaya sendiri atau out-ofpocket (OOP) yang tinggi. Biaya OOP yang tinggi merupakan disinsentif bagi orang untuk mengakses perawatan yang mereka butuhkan dan dapat menjadi bencana besar bagi rumah tangga yang lebih miskin. ${ }^{1}$

Badan Penyelenggara Janiman Sosial atau BPJS adalah lembaga yang diselenggarakan untuk Program Jaminan Sosial bidang kesehatan di Indonesia berdasarkan Undang-Undang Nomor 40 Tahun 2004 berisi tentang Sistem Jaminan Sosial Nasional (SJSN) yang dimulai pada tanggal 01 Januari 2014. Undang-Undang Nomor 24 Tahun 2011 berisi tentang BPJS yang terbagi dua yaitu, BPJS Kesehatan dan BPJS Ketenagakerjaan. Dalam setiap pelaksanaan program kerja yang dilakukan oleh BPJS, bertanggung jawab langsung kepada Presiden untuk setiap pelaporan. BPJS memiliki kewenangan untuk menagih iuran yang harus dibayarkan peserta BPJS, penempatan dana sesuai kebutuhan, melakukan pengawasan dan pemeriksaan atas kepatuhan peserta dan pemberi kerja. Program jaminan kesehatan dijalankan secara rasional dengan prinsip asuransi sosial, prinsip ekuitas dan sistem kerjanya yaitu bergotong-royong, dimana peserta yang mampu dan sehat akan membantu peserta yang kurang mampu dan sedang sakit. ${ }^{2}$

Bentuk upaya yang dilakukan oleh pemerintah untuk memberikan pelayanan kesehatan bagi masyarakat yaitu dengan memberikan jaminan kesehatan bagi masyarakat yaitu dengan membentuk
Badan Penyelenggara Jaminan Sosial (BPJS). ${ }^{3}$ Hasil analisis BPJS Kesehatan terjadi peningkatan persentase yaitu pada tingkat kepuasan peserta BPJS Kesehatan dan tingkat kepuasan fasilitas kesehatan (faskes) rekanan. Tercatat pada tahun 2017 BPJS Kesehatan didapatkan indeks kepuasan peserta sebanyak $79,5 \%$, dan indeks kepuasan faskes sebesar 89,5\%. Sedangkan pada tahun 2016 indeks kepuasan peserta sebesar 78,6\% dan fasilitas kesehatan $76,2 \%{ }^{4}$

Pelayanan kesehatan yang kurang baik akan menimbulkan rasa kecewa bagi para peserta BPJS Kesehatan. Adanya rasa kurang empati para tenaga kesehatan yang memberikan pelayanan Kesehatan terhadap peserta BPJS. $^{5}$ Riset yang dilakukan oleh Perkumpulan Prakarsa di 11 kabupaten/kota yang melibatkan 1.334 responden rumah tangga menunjukkan beragam keluhan yang dirasakan dalam prosedur pemeriksaan dokter. Penelitian tersebut menyatakan bahwa sebesar 50,57 $\%$ responden merasa bahwa dokter kurang peduli, sebanyak $14,94 \%$ merasa tenaga kesehatan kurang komunikatif dan sebesar $12,64 \%$ merasa dokter tidak datang tepat waktu. ${ }^{6}$

Indikator untuk melihat tingkat keberhasilan suatu pelayanan kesehatan yaitu dengan menilai tingkat kepuasan yang dirasakan oleh pasien. Kepuasan yang dirasakan oleh pasien dapat dijadikan suatu evaluasi untuk menilai kualitas pelayanan kesehatan yang diberikan oleh instansi penyelenggara pelayanan kesehatan seperti Rumah Sakit, Klinik, dll. Sehingga hal ini dapat mencerminkan kemampuan penyedia layanan untuk memenuhi kebutuhan pasien. ${ }^{7}$ Konsep mutu layanan yang berkaitan dengan kepuasan pasien ditentukan oleh lima unsur yang biasa dikenal dengan istilah mutu layanan atau service quality yaitu kehandalan (reliability), ketanggapan (responsiveness), jaminan (assurance), empati (empathy) dan bukti fisik (tangiable). ${ }^{8}$ 
Penelitian sebelumnya yang dilakukan oleh Zumria dan Narmi menemukan bahwa terdapat perbedaan tingkat kepuasan pasien BPJS dan Non BPJS terhadap Mutu Pelayanan di Ruang Rawat Inap RSUD Kota Kendari pada dimensi tangible, reliability, responsiveness, assurances dan empathy. ${ }^{9}$ Penelitian tersebut merekomendasikan kepada pihak RSUD Kota Kendari sebagai penyelanggara fasilitas dan pelayanan Kesehatan agar senantiasa dapat selalu memperbaiki dan meningkatkan terhadap pelayanan pasien rawat inap tanpa membedakan status BPJS maupun Non BPJS. ${ }^{9}$

Hasil studi pendahuluan yang dilakukan oleh peneliti tentang kepuasan pasien BPJS terhadap mutu pelayanan kesehatan di RS Bhakti Husada melalui proses wawancara dan penyebaran kuesioner, diketahui bahwa dari 20 responden (pasien BPJS Kesehatan) menunjukkan bahwa sebanyak 14 responden $(70 \%)$ menyatakan puas dan 6 responden $(30 \%)$ yang menyatakan tidak puas. Namun, dari sebagian besar pasien yang telah menyatakan puas masih terdapat keluhan mengenai pelayanan kesehatan yang ada di RS tersebut, salah satu keluhan yang paling banyak dikeluhkan adalah pasien yang harus menunggu lama hingga dipanggil untuk mendapatkan pelayanan kesehatan. Berdasarkan permasalahan tersebut, maka penelitian ini bertujuan untuk mengetahui hubungan mutu pelayanan kesehatan terhadap tingkat kepuasan pasien BPJS kesehatan.

\section{Metode}

Penelitian ini menggunakan analisis kuantitatif observasional dengan desain analitik cross sectional. Artinya pengambilan data antara variabel independen yaitu kualitas pelayanan kesehatan (reliability, responsiveness, assurance, emphaty, dan tangible) dan variabel dependen yaitu kepuasan pasien BPJS kesehatan dilakukan dalam waktu yang bersamaan. Pengolahan data menggunakan aplikasi SPSS versi 23, serta analisa data menggunakan uji Chi-Square. Penelitian ini dilaksanakan selama dua minggu, yakni dari tanggal 4-16 Mei 2020 di Rumah Sakit Bhakti Husada. Populasi dari penelitian ini adalah seluruh pasien yang pernah datang berobat di Rumah Sakit Bhakti Husada khususnya pada pelayanan rawat jalan dalam kurun waktu Januari-Desember 2019 yaitu sebanyak 46.347 pasien.

Dalam pengambilan sampel menggunakan teknik accidental sampling (non-probability sampling) dan didapatkan jumlah sampel sebanyak 100 pasien. ${ }^{10}$ Pengumpulan data dilakukan dengan memberikan kuisioner kepada setiap responden yang yang memenuhi syarat inklusi dan eksklusi dalam penelitian ini. Syarat inklusi yaitu setiap pasien yang berkunjung di pelayanan rawat jalan Rumah Sakit Bhakti Husada yang bersedia menjadi reponden sedangkan syarat eksklusi dalam penelitian ini yaitu pasien yang berkunjung di pelayanan rawat jalan Rumah Sakit Bhakti Husada yang tidak bersedia menjadi reponden. Selanjutnya data yang diperoleh akan diolah dengan menggunakan uji statistik yaitu teknik univariat, dan analisis bivariat dengan $\mathrm{Chi}$ Square menggunakan alpha 0,05. Hasil penelitian disajikan dalam bentuk tabel disertai narasi.

\section{Hasil}

Sampel dalam penelitian ini berjumlah 100 responden, Hasil penelitian menunjukkan responden dengan jenis kelamin wanita $(51 \%)$ lebih banyak dibandingkan responden laki-laki (49\%). Karakteristik berdasarkan usia responden paling banyak berusia $17-35$ tahun (50\%), kemudian usia 35-50 tahun (38\%) dan paling sedikit berusia $>50$ tahun responden (12\%). Selanjutnya karakteristik berdasarkan pendidikan responden yaitu paling banyak bependidikan SMA (61\%), berpendidikan SMP (16\%), berpendidikan SD $(12 \%)$ dan yang paling sedikit sedikit 
Tabel 1. Distribusi Karakteristik Responden di Rumah Sakit Bhakti Husada

\begin{tabular}{clcc}
\hline \multicolumn{1}{c}{ Variabel } & \multicolumn{1}{c}{ Kategori } & n & \% \\
\hline Jenis Kelamin & Laki-laki & 49 & 49 \\
& Perempuan & 51 & 51 \\
Usia (tahun) & $17-35$ & 50 & 50 \\
& $35-50$ & 38 & 38 \\
& $>50$ & 12 & 12 \\
Pendidikan & SD & 12 & 12 \\
& SMP & 16 & 16 \\
& SMA & 61 & 61 \\
Penghasilan & Pendidikan Tinggi & 11 & 11 \\
& $\leq$ Rp. 2.500.000 & 25 & 25 \\
& $\geq$ Rp. 2.500.000 & 75 & 75 \\
\hline
\end{tabular}

Tabel 2. Hubungan antara Mutu Pelayanan dengan Kepuasan Pasien di Rumah Sakit Bhakti Husada

\begin{tabular}{|c|c|c|c|c|c|c|c|}
\hline \multirow{3}{*}{ Variabel } & \multirow{3}{*}{ Kategori } & \multicolumn{4}{|c|}{ Kepuasan Pasien } & \multirow{3}{*}{$\begin{array}{c}\mathbf{P} \\
\text { value }\end{array}$} & \multirow{3}{*}{$\begin{array}{c}\text { OR } \\
(95 \% \mathrm{CI})\end{array}$} \\
\hline & & \multicolumn{2}{|c|}{ Puas } & \multicolumn{2}{|c|}{ Tidak Puas } & & \\
\hline & & $\mathbf{n}$ & $\%$ & $\mathbf{n}$ & $\%$ & & \\
\hline Reliability & Handal & 76 & 81,7 & 17 & 18,3 & 0,000 & \\
\hline (Kehandalan) & Tidak handal & 0 & 0,0 & 7 & 100 & & \\
\hline Responsiveness & Tanggap & 67 & 97,1 & 2 & 2,9 & 0,000 & 81,889 \\
\hline (Ketanggapan) & Tidak tanggap & 9 & 29,0 & 22 & 71,0 & & $(16,433-408,073)$ \\
\hline Assurance & Terjamin & 75 & 80,6 & 18 & 19,4 & 0,001 & 25.000 \\
\hline (Jaminan) & Tidak terjamin & 1 & 14,3 & 6 & 85.7 & & $(2,830-220,850)$ \\
\hline Emphaty & Empati & 74 & 90,2 & 8 & 9,8 & 0,000 & 74,000 \\
\hline (Empati) & Tidak empati & 2 & 11,1 & 16 & 88,9 & & $(14,340-381,868)$ \\
\hline Tangible & Baik & 72 & 85,7 & 12 & 14,3 & 0,000 & 18,000 \\
\hline (Bukti fisik) & Tidak baik & 4 & 25,0 & 12 & 75,0 & & $(4,974-65,133)$ \\
\hline
\end{tabular}

berpendidikan perguruan tinggi (11\%). Berdasarkan karakteristik penghasilan responden sebagian besar memiliki penghasilan $\geq$ Rp. $2.500 .000 \quad(75 \%)$ dan sisanya memiliki penghasilan sebanyak $\leq$ Rp. 2.500 .000 (25\%).

Tabel 2 menunjukkan terdapat hubungan yang signifikan antara masingmasing dimensi mutu layanan, yaitu (tangiable $\quad(0,000), \quad$ kehandalan (reliability) $\quad(0,000), \quad$ ketanggapan (responsiveness) $(0,000), \quad$ jaminan (assurance) $(0,001)$ dan empati (empathy) $(0,000)$ dengan kepuasan pasien yang berarti bahwa antara tiap variabel tersebut memiliki hubungan yang bermakna. Dimensi variabel yang paling berpengaruh yaitu ketanggapan (responsiveness) dengan nilai OR sebesar 81,889 (16,433-408,073).

\section{Pembahasan}

Penelitian ini menunjukkan bahwa masing-masing dimensi mutu pelayanan memiliki hubungan (tangiable), kehandalan (reliability), ketanggapan (responsiveness), jaminan (assurance) dan empati (empathy) dengan kepuasan pasien BPJS di Rumah Sakit Bhakti Husada. Pasien BPJS menyampaikan bahwa petugas RS dalam memberikan pelayanan sudah cukup baik, seperti pasien dilayani dengan cukup cepat, petugas memberikan pelayanan cukup tepat waktu dan pelayanan tidak berbelit-belit. Hasil penelitian ini sejalan dengan penelitian 
yang dilakukan oleh Lahdji, dkk yang menunjukkan bahwa terdapat hubungan yang bermakna antara kepuasan pasien terhadap dimensi responsiveness. ${ }^{11}$

Berdasarkan hasil uji statistik pada dimensi reliability (kehandalan) menunjukkan bahwa terdapat hubungan yang bermakna dengan kepuasan pasien BPJS kesehatan. Sebagian besar responden yang menyatakan puas terhadap layanan BPJS juga menyatakan petugas kesehatan handal. Pasien BPJS menyampaikan bahwa pelayanan yang ada di RS cukup sudah baik, seperti petugas rumah sakit yang tidak membeda-bedakan status pasien, pemberian informasi yang jelas oleh petugas medis dan selalu siap dilayani oleh para petugas medis. Hasil penelitian ini sejalan dengan penelitian yang dilakukan Wandini, dkk yang menunjukkan bahwa terdapat hubungan yang bermakna antara kepuasan pasien terhadap dimensi reliability. ${ }^{12}$ Hasil penelitian tersebut menyebutkan bahwa sebanyak 71,9 \% responden mengatakan baik terhadap pelayanan dokter dan $76 \%$ responden mengatakan baik terhadap pelayanan keperawatan.

Hasil uji statistik menunjukkan bahwa terdapat hubungan yang bermakna antara kepuasan pasien BPJS terhadap dimensi assurance. Data menunjukkan bahwa Sebagian besar responden yang menyatakan puas terhadap layanan BPJS juga menyatakan terjamin. Sebagian besar responden pasien BPJS menyatakan puas terhadap jaminan yang diberikan oleh RS, seperti pasien dilayani dengan ramah dan sopan, pasien merasa nyaman dan aman pada saat mendapatkan pelayanan, serta petugas $\mathrm{RS}$ yang tidak bersikap ragu-ragu atau membahayakan dalam melayani pasien. Hasil penelitian ini sejalan dengan penelitian yang dilakukan oleh Aminilia yang menunjukkan bahwa tingkat persepsi kualitas dan kepuasan pasien yaitu termasuk dalam kategori cukup baik. Penelitian tersebut menyimpulan bahwa untuk semua variabel dari dimensi kulaitas pelayanan yaitu bukti kehandalan, fisik, jaminan, empati dan ketanggapan menunjukkan adanya pengaruh yang signifikan terhadap kepuasan pasien rawat jalan $^{14}$.

Hasil uji statistik didapatkan data bahwa terdapat hubungan yang bermakna antara kepuasan pasien BPJS terhadap dimensi emphaty (empati). Sebagian besar responden yang menyatakan puas terhadap layanan BPJS juga menyatakan empati. Pasien BPJS merasakan bahwa pelayanan yang di berikan oleh RS sudah cukup baik, seperti halnya petugas medis yang berpenampilan baik, pasien mendapatkan informasi yang cukup jelas mengenai status kesehatannya hingga pasien mengatakan bahwa petugas medis sudah cukup datang tepat waktu sesuai jadwal yang diinformasikan. Hasil tersebut sejalan dengan penelitian yang dilakukan oleh Purwaningrum yang menunjukkan adanya hubungan antara semua dimensi mutu pelayanan kesehatan dengan kepuasan pasien. Penelitian tersebut juga menyimpulkan bahwa variabel empati merupakan variabel yang paling dominan terhadap kepuasan pasien pengguna jasa BPJS. $^{15}$

Hasil uji statistik menunjukkan bahwa terdapat hubungan yang bermakna antara kepuasan pasien BPJS terhadap dimensi tangible. Pada dimensi tangible, sebagian besar pasien yang menyatakan puas terhadap layanan BPJS juga menyatakan bukti fisik baik. Penilaian dalam dimensi ini adalah bukti fisik atau secara nyata yang terlihat oleh pasien yang datang berkunjung seperti fasilitas-fasilitas yang ada di RS. Pasien BPJS yang berkunjung mengatakan bahwa fasilitas yang ada di RS sudah cukup baik, seperti peralatan yang digunakan dalam kondisi baik, ruang tunggu yang cukup nyaman dan bersih, serta kejelasan mengenai alur pelayanan yang ada di RS. Penelitian ini tidak sejalan dengan penelitian yang dilakukan oleh Widodo yang menyebutkan ada hubungan yang signifikan antara kepuasan pasien BPJS terhadap dimensi tangible. ${ }^{16}$ 


\section{Kesimpulan}

Berdasarkan hasil penelitian yang telah dilakukan oleh peneliti dapat ditarik kesimpulan yaitu adanya hubungan yang bermakna antara mutu pelayanan kesehatan (reliability, responsiveness, assurance, emphaty, dan tangible) dengan kepuasan pelayanan yang dirasakan oleh pasien peserta BPJS Kesehatan. Adapun hasil penelitian ini menunjukkan bahwa kualitas mutu pelayanan yang baik berhubungan dengan kepuasaan pelayanan yang dirasakan pasien BPJS Kesehatan.

\section{Saran}

RS Bhakti Husada diharapkan dapat mempertahankan dan meningkatkan mutu pelayanan kesehatan yang sudah baik terutama pada kelima dimensi (reliability, responsiveness, assurance, emphaty, dan tangible) serta dapat meningkatkan kembali mutu pelayanan yang kurang baik seperti memberikan pelayanan kesehatan dengan lebih professional, perbaikan fasilitas sarana dan prasarana yang digunakan serta lebih ditingkatkan kembali dalam hal keramahan petugas RS agar pasien merasa lebih senang, nyaman, dan dihargai serta meraka akan merekomendasikan RS Bhakti Husada kepada orang lain. Penelitian selanjutnya diharapkan dapat melanjutkan penelitian ini dengan menambah jumlah responden atau melakukan perbandingan antara Rumah Sakit yang memiliki kesamaan karakteristik.

\section{Daftar Pustaka}

1. Annie Chu, Soonman Kwon PC. Health Financing Reforms for Moving towards Universal Health Coverage in the Western Pacific Region. Heal Syst Reform. 2019;5(1):32-47. doi:10.1080/23288604.2018.1544029

2. Pemerintah Republik Indonesia. Undang Undang Republik Indonesia No 24 Tahun 2011 Tentang BPJS. Vol 16.; 2011.

3. Widiastuti I. Pelayanan Badan Penyelenggara Jaminan Sosial (BPJS) Kesehatan Di Jawa Barat. Public Inspir J Adm Publik. 2017;2:91-
101.

4. BPJS Kesehatan. Ringkasan Eksekutif Pengelolaan Program dan Laporan Keuangan Jaminan Sosial Kesehatan. BPJS Kesehat. Published online 2016:1-20. https://www.bpjs-

kesehatan.go.id/bpjs/dmdocuments/b39df9ae7 a30a5c7d4bd0f54d763b447.pdf

5. Abidin. Pengaruh Kualitas Pelayanan BPJS Kesehatan terhadap Kepuasan Pasien di Puskesmas Cempae Kota Parepare. Mkmi. 2016;12(2):70-75.

6. Umniyati H. Kepuasan pasien terhadap pelayanan tenaga kesehatan di Puskesmas Kecamatan Tanjung Priok Jakarta Utara Tahun 2009. J Kedokt Yars. 2010;18(1):9-20. https://media.neliti.com/media/publications/10 5017-ID-kepuasan-pasien-terhadappelayanan-tenag.pdf

7. Mailani F, Fitri N. Hubungan Perilaku Caring Perawat Dengan Tingkat Kepuasan Pasien Bpjs Di Ruang Rawat Inap Rsud Dr. Rasidin Padang. J Endur. 2017;2(2):203. doi:10.22216/jen.v2i2.1882

8. Arif Tarmansyah Iman DL. Manajemen Mutu Informasi Kesehatan 1: Quality Assurance. Kementrian Kesehatan RI; 2017.

9. Zumria, Narmi T. Perbedaan Tingkat Kepuasan Pasien Bpjs Dan Non Bpjs Terhadap Mutu Pelayanan Di Ruang Rawat Inap RSUD Kota Kendari. J Ilm Karya Kesehat. 2020;1(1):76-83.

10. Saryono. Metodologi Penelitian Kebidanan DIII, DIV, S1 Dan S2.; 2011.

11. Lahdji A, Setiawan MR, Purnamasari WI. Faktor Faktor yang Mempengaruhi Mutu Pelayanan Kesehatan terhadap Kepuasan Pasien BPJS di Klinik Penyakit Dalam RSUD Sunan Kalijaga Demak Periode Mei-Oktober 2015. J Kedokt Muhammadiyah. 2015;5(2):17.

12. Wandini, R., \& Triyoso T. Hubungan Mutu Pelayanan Terhadap Tingkat Kepuasan Pasien BPJS di Rumah sakit Pertamina Bintang Amin Bandar Lampung Tahun 2016. Holistik J Kesehat. 2016;10(3):133-139.

13. M Dana Prihadi EE. Analisis Persepsi Kualitas Pelayanan Rawat Jalan Poli Internis terhadap Kepuasan Pasien RSUD Cibabat Cimahi. J Manaj Inf Kesehat Indones. 2021;9(1):40-49.

14. Aminilia SW. Analisis Tingkat Kepuasan Pasien Terhadap Mutu Pelayanan Kesehatan Pada Pasien BPJS Di Rawat Jalan Rumah Sakit Khusus Daerah Duren Sawit Jakarta Tahun 2017. J Kesehat Masy. 2018;2(1).

15. Purwaningrum R. Analisis Mutu Pelayanan Terhadap Kepuasan Pasien Di Rumah Sakit Pertamina Bintang Amin Bandar Lampung Tahun 2018. J Ilmu Kedokt dan Kesehat. 
2020;7(1):357-367.

doi:10.33024/jikk.v7i1.2418

16. Widodo S. Analisis Tingkat Kepuasan Pasien

Terhadap Mutu Pelayanan Kesehatan Pada
Pasien BPJS Di Rawat Jalan Rumah Sakit Khusus Daerah Duren Sawit Jakarta Tahun 2017. J Kesehat Masy. 2018;2(1):1-1 